\title{
Vaccine Against Covid-19 Disease - Present Status of Development
}

\author{
Ashok Kumar Dutta ${ }^{1}$
}

Received: 5 August 2020 / Accepted: 16 August 2020 / Published online: 3 September 2020

(C) Dr. K C Chaudhuri Foundation 2020

\begin{abstract}
The pandemic declaration of Covid-19 disease by World Health Organization (WHO) and subsequent widespread morbidities and mortalities in almost all countries of the world led to the research and development to find out a vaccine against SARS-CoV2 virus. Normally any new vaccine development takes $10-15 \mathrm{y}$ time but the search for vaccine against SARS-CoV2 is going on at a very fast pace resulting in almost breakthrough in vaccine development by several research institutions and vaccine manufacturers. In pandemic situation, however, the entire process of vaccine development including clinical trials gets shortened and may be fast tracked to $15-18$ mo time. It is expected that there shall be simultaneous marketing of several vaccines by the beginning of 2021. There are more than 164 candidate vaccines which are in the process of development and among them 24 vaccines are in advanced stages of development. This review aims at highlighting the present stages of development of vaccines and discussing the challenges that may be faced with these novel vaccines.
\end{abstract}

Keywords SARS-CoV2 $\cdot$ Covid-19 $\cdot$ Vaccine against SARS-CoV2

\section{Introduction}

On 30th January, 2020 World Health Organization (WHO) declared a severe respiratory disorder syndrome which originated in Wuhan city as a global public health emergency and on 11th February named the disease as Covid-19. The pandemic declaration by WHO was made on 11th March 2020. The spread of Covid-19 is now relentless and the spread in almost all the countries of the world is causing serious public health, social and economic upheaval. Vaccine is one of the best armamentaria in public health especially where no effective treatment is available against a disease. Since the declaration of outbreak of Covid-19, there is a race for development of a safe and effective vaccine against SARS-CoV2. As of 21 st July 2020, the landscape of SARS-Cov2 vaccine development in the world shows that there are 24 vaccines that are in advance stages and another 142 vaccines are also in various early stages of development $[1,2]$.

Ashok Kumar Dutta drdutta@gmail.com

1 Indraprastha Apollo Hospital, New Delhi, India

\section{Stages of Vaccine Development [3]}

Vaccine development consists of following steps e.g., exploratory, preclinical and clinical stages.

Exploratory stage deals with basic research in the laboratory regarding the conceptual idea and development of an antigen against the disease against which vaccine needs to be produced. It usually takes $2-4$ y time.

Preclinical stage: This stage of development uses a platform of tissue-culture or cell-culture systems and animal testing to assess the safety of the candidate vaccine and its immunogenicity. Animal studies using mice, rabbits, guinea pigs, monkeys etc., according to the antigens, are used to find out the immune response and also side-effects related to the candidate vaccine. These studies provide researchers an idea of the cellular responses they might expect in humans. They may also suggest the safest starting dose for the next phase of research as well as the safest method of administering the vaccine. Many researchers in this stage try challenging the animals with the offending organisms to find out the efficacy in preventing the infection or severity of the disease. This stage usually takes $1-2 \mathrm{y}$ and out of 100 potential candidates, 6 usually pass through this stage. The regulatory authority is informed about the candidate vaccine with full data and the sponsor company for manufacturing and undertaking the next clinical stages is identified'. 
Clinical stages of development consist of at least 3 stages and the 4th post-marketing safety assessment is also mandatory.

Clinical trial phase I: In Phase I, a small number of healthy adult volunteers usually between 20 and 80 subjects are administered the candidate vaccine. If the vaccine is intended for children, researchers will first test adults, and then gradually step down the age of the test subjects until they reach their target. Phase I trial is usually an open label trial where both researchers and subjects are aware of what vaccine has been given. The aim of phase I trial is to assess the safety as well the type of immune response the candidate vaccine may produce. In some of the instances, in this stage, the participants are challenged with the pathogens under carefully monitored and controlled environment to find the real effect of the vaccine. The data is analyzed and if it shows promising result, the trial progresses to the next phase.

In Phase II vaccine trial, a larger group of several hundred individuals participate in testing. Some of the individuals may belong to the groups at risk of acquiring the disease. These trials are randomized and well controlled, and include a placebo group.

The goals of Phase II testing are to study the candidate vaccine's safety, immunogenicity, proposed doses, schedule of immunization, and route of administration.

In Phase III of the trial, vaccine safety in a large group of people is tested. If the chance of side-effects is 1:1000, then a sample size of approximately 60,000 subjects is to be included in the trial. In this stage the immunogenicity of the trial vaccine is tested, e.g., production of critical level of antibodies/ cell-mediated immunity and also whether it prevents infection by the infecting agent as well as protects from the disease.

After a successful Phase III trial, the vaccine manufacturer shall submit application for biological license of the product to the licensing authority (in India, it is Drug Controller General of India). The licensing authority then physically verifies the vaccine and if satisfied, gives permission.

The licensing authority constantly monitors the adverse reactions following vaccination as a post-licensure process. Many manufacturing companies undertake a Phase IV trial for safety, efficacy and other potential uses which are optional studies after a vaccine is released.

In normal circumstances, the entire process of development of a new vaccine takes approximately $10-15$ y time. However in pandemic situation, taking into consideration the urgency, there is overlapping of clinical trial phases and the entire process can be advanced to 12 mo-18 mo time as shown in Fig. 1 [4].

\section{Landscape of SARS-CoV2 Vaccine Development}

As of 21 st July, 2020 according to WHO there are 24 candidate vaccines which are in advanced stages of development
(Table 1) and another 142 are in preclinical stages. All the following 24 candidate vaccines are either in Phase 1, 2 or 3 clinical trial stages and many have shown encouraging results after animal studies. Most of these vaccines are being developed in USA, Europe and China. In India there are two candidate vaccines (Bharat Biotech and Zydus Cadila) which are in advance stages of development and an another manufacturing company (Serum Institute of India), in collaboration with Oxford University and Astra Zeneca shall be starting the Phase 3 trial and if found effective, shall start large scale production of the vaccine.

\section{Diversity of Various Technology Platforms for Development of Covid-19 Vaccine}

Coronaviruses are enveloped, positive sense single-stranded RNA viruses with a glycoprotein spike on the surface, which mediates receptor binding and cell entry during infection. The roles of the spike protein in receptor binding and membrane fusion make it an attractive vaccine antigen. Almost all manufacturers are targeting spike protein as antigen apart from whole virion inactivated vaccine.

There are multiple methods and platforms being tried for the development of this vaccine. Traditionally, vaccines are manufactured either as inactivated, live attenuated or subunit, but various institutions and manufacturers are trying next generation techniques. Probably the world shall witness many new platforms through which Covid-19 vaccine shall be developed. It is expected that the first RNA vaccine may find a place in the history of vaccine development as a successful agent for prevention of Covid-19. Besides this, DNA, vector based RNA, subunit and many other variants of RNA technologies are undergoing trial in the making of SARS-CoV2 vaccine. The concept of messenger RNA vaccine is relatively new but relatively simple in which mRNA coding for the spike protein is injected and the host produces the antibody and can be manufactured in an industrial scale.

In this review, a brief outline of a few vaccines which are in advance stages of development and those for which data has been published shall be discussed.

\section{ChAdOx1 nCoV-19}

This is one of the most discussed vaccine being developed by Oxford university in collaboration with Astra Zaneca and has completed Phase 1/2 trial and is about to begin Phase 3 trial in several countries. This vaccine was initially tried in mice and Rhesus macaques which showed good immunogenicity but when challenged with SARS-CoV2 virus through different routes, it did not prevent naso-pharyngeal colonization but prevented pneumonia. The authors expressed their views that the same situation of multiple routes of transmission will not take place in human beings [5]. In a recently concluded 


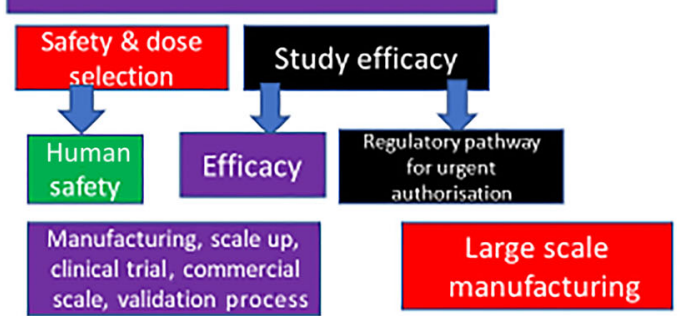

- Normal vaccine development-10-15 y

\section{- In pandemic situation-Overlapping phases in development (12-15) mo}

Fig. 1 Pandemic enhanced paradigm of vaccine development

randomized control trial with the same vaccine in human subjects, 543 healthy human subjects aged $18-55$ y were challenged with a single dose of the trial vaccine and 534 age and sex control subjects were administered Menectra.

ChAdOx1 nCoV-19 elicited an increase in spike-specific antibodies by day 28 and neutralising antibody in all participants after a booster dose. High levels of neutralising antibody at baseline seen in a small number of participants probably indicates prior asymptomatic infection, as potential participants with recent COVID-19 like symptoms or with a history of positive PCR test for SARS-CoV2 were excluded from the study. Individuals with high titres on the day of vaccination who received ChAdOx1 nCoV-19 were boosted by vaccination. Although a correlate of protection has not been defined for Covid-19, high levels of neutralising antibodies have been shown in convalescent individuals, with a wide range, as confirmed in the study. There was no significantly higher moderate or severe adverse reaction to the vaccine compared to the control group [6]. Although this study showed good antibody response following single dose, the authors have observed better response after a booster dose. Following the result of the present study, a Phase 3 clinical trial with several thousand subjects has already started and the results would clarify whether single or two doses are required and also the duration of persistence of protecting antibody levels in different ethnic groups and high risk individuals including children.

\section{Cansino Biologicals China}

Cansino Biologicals' (Tianjin, China) adenovirus type-5 (Ad5)-vectored Covid-19 vaccine, in an open label trial had observed that the higher dose of the vaccine was associated with severe adverse reactions in human beings. Therefore in the Phase 2 double blind placebo controlled study, a smaller dose with large number of subjects was included to determine the immunogenicity and adverse reactions as well as the appropriate dose. The study evaluated 508 healthy subjects who were assigned to three groups: 253 who received $1 \times$ $10^{11}$ viral particles, 129 subjects were injected $5 \times 10^{5}$ virus particles and the rest 126 were assigned to the placebo group. Seroconversion of the neutralising antibody responses to live SARS-CoV2 occurred in $148(59 \%, 95 \%$ CI 52-65) of 253 participants receiving the $1 \times 10^{11}$ viral particles dose, and in $61(47 \%, 39-56)$ of 129 participants receiving the $5 \times 10^{10}$ viral particles dose $28 \mathrm{~d}$ post vaccination. Positive specific $\mathrm{T}$ cell responses measured by IFN $\gamma$-ELISpot were found in $90 \%$ and $88 \%$ of participants receiving the vaccine at $1 \times 10^{11}$ and $5 \times 10^{10}$ viral particles, respectively. $95 \%$ of participants in the $1 \times 10^{11}$ viral particles dose group and $91 \%$ of the recipients in the $5 \times 10^{10}$ viral particles dose group showed either cellular or humoral immune responses at day 28 post vaccination. There was no significant adverse reactions to any of the group although the study was not powered enough for severe adverse reactions.

The study shows the neutralizing antibody titre to be low and the need for booster. Moreover, different ethnic groups including high risk individuals were not studied [7].

\section{Moderna Vaccine mRNA-1273}

In primate rhesus monkey, the mRNA-1273 vaccine candidate induced antibody levels exceeding those in human convalescent phase serum, with live virus reciprocal $50 \%$ inhibitory dilution (ID50) geometric mean titers of 501 in the $10 \mu \mathrm{g}$ dose group and 3481 in the $100 \mu \mathrm{g}$ dose group. Vaccine induced type 1 helper T-cell based CD4 T-cell response was found to be good whereas no or low Th2 or CD8 cell response was found. Viral replication was not detectable in bronchoalveolar lavage (BAL) fluid by day 2 after challenge in seven of eight animals in both vaccinated groups. No viral replication was detectable in the nose of any of the eight animals in the $100 \mu \mathrm{g}$ dose group by day 2 
Table 1 DRAFT landscape of COVID-19 candidate vaccines - 21 July 2020

\begin{tabular}{|c|c|c|c|c|c|}
\hline Platform & Type of candidate vaccine & Developer & $\begin{array}{l}\text { Coronavirus } \\
\text { target }\end{array}$ & $\begin{array}{l}\text { Current stage of clinical } \\
\text { evaluation/regulatory } \\
\text { status- Coronavirus candi- } \\
\text { date }\end{array}$ & $\begin{array}{l}\text { Same platform for } \\
\text { non-Coronavirus } \\
\text { candidates }\end{array}$ \\
\hline Inactivated & Inactivated + alum & Sinovac & SARS-CoV2 & $\begin{array}{l}\text { Phase } 3 \\
\text { NCT04456595 } \\
\text { Phase } 1 / 2 \\
\text { NCT04383574 } \\
\text { NCT04352608 }\end{array}$ & SARS \\
\hline Inactivated & Inactivated & $\begin{array}{l}\text { Wuhan Institute of Biological } \\
\text { Products/Sinopharm }\end{array}$ & SARS-CoV2 & $\begin{array}{l}\text { Phase } 3 \\
\text { ChiCTR2000034780 } \\
\text { Phase } 1 / 2 \\
\text { ChiCTR2000031809 }\end{array}$ & \\
\hline Inactivated & Inactivated & $\begin{array}{l}\text { Beijing Institute of Biological } \\
\text { Products/Sinopharm }\end{array}$ & SARS-CoV2 & $\begin{array}{l}\text { Phase } 3 \\
\text { ChiCTR2000034780 } \\
\text { Phase } 1 / 2 \\
\text { ChiCTR2000032459 }\end{array}$ & \\
\hline $\begin{array}{l}\text { Non-Replicating } \\
\text { Viral Vector }\end{array}$ & ChAdOx1-s & $\begin{array}{l}\text { University of } \\
\text { Oxford/AstraZeneca }\end{array}$ & SARS-CoV2 & $\begin{array}{l}\text { Phase } 3 \\
\text { ISRCTN89951424 } \\
\text { Phase } 2 \mathrm{~b} / 3 \\
\text { 2020-001228-32 } \\
\text { Phase } 1 / 2 \\
\text { PACTR202006922165132 } \\
\text { 2020-001072-15 }\end{array}$ & $\begin{array}{l}\text { MERS, influenza, } \\
\text { TB, } \\
\text { Chikungunya, } \\
\text { Zika, MenB, } \\
\text { plague }\end{array}$ \\
\hline $\begin{array}{l}\text { Non-Replicating } \\
\text { Viral Vector }\end{array}$ & $\begin{array}{l}\text { Adenovirus type } \\
5 \text { vector }\end{array}$ & $\begin{array}{l}\text { CanSino Biological Inc./Beijing } \\
\text { Institute of Biotechnology }\end{array}$ & SARS-CoV2 & $\begin{array}{l}\text { Phase } 2 \\
\text { ChiCTR2000031781 } \\
\text { Phase } 1 \\
\text { ChiCTR2000030906 }\end{array}$ & Ebola \\
\hline Protein Subunit & $\begin{array}{l}\text { Adjuvanted recombinant } \\
\text { protein (RBD-Dimer) }\end{array}$ & $\begin{array}{l}\text { Anhui Zhifei Longcom } \\
\text { Biopharmaceutical/ Institute } \\
\text { of Microbiology, Chinese } \\
\text { Academy of Sciences }\end{array}$ & SARS-CoV2 & $\begin{array}{l}\text { Phase } 2 \\
\text { NCT04466085 } \\
\text { Phase } 1 \\
\text { NCT04445194 }\end{array}$ & MERS \\
\hline RNA & LNP-encapsulated mRNA & Moderna/NIAID & SARS-CoV2 & $\begin{array}{l}\text { Phase } 3 \text { (not yet recruiting) } \\
\text { NCT0 } 4470427 \\
\text { Phase } 2 \\
\text { NCT0 } 4405076 \\
\text { Phase } 1 \\
\text { NCT04283461 }\end{array}$ & $\begin{array}{l}\text { multiple } \\
\text { candidates }\end{array}$ \\
\hline DNA & $\begin{array}{l}\text { DNA plasmid vaccine } \\
\text { with electroporation }\end{array}$ & $\begin{array}{l}\text { Inovio Pharmaceuticals/ } \\
\text { International Vaccine } \\
\text { Institute }\end{array}$ & SARS-CoV2 & $\begin{array}{l}\text { Phase } 1 / 2 \\
\text { NCT04447781 } \\
\text { NCT04336410 }\end{array}$ & $\begin{array}{l}\text { multiple } \\
\text { candidates }\end{array}$ \\
\hline DNA & $\begin{array}{l}\text { DNA plasmid vaccine }+ \\
\text { Adjuvant }\end{array}$ & $\begin{array}{l}\text { Osaka University/ AnGes/ } \\
\text { Takara Bio }\end{array}$ & SARS-CoV2 & $\begin{array}{l}\text { Phase } 1 / 2 \\
\text { NCT0 } 4463472\end{array}$ & \\
\hline DNA & DNA vaccine (GX-19) & Genexine Consortium & SARS-CoV2 & $\begin{array}{l}\text { Phase } 1 / 2 \\
\text { NCT0 } 4445389\end{array}$ & \\
\hline DNA & DNA plasmid vaccine & Cadila Healthcare Limited & SARS-CoV2 & $\begin{array}{l}\text { Phase } 1 / 2 \\
\text { CTRI/2020/07/026352 }\end{array}$ & \\
\hline Inactivated & Whole-virion Inactivated & Bharat Biotech & SARS-CoV2 & $\begin{array}{l}\text { Phase } 1 / 2 \\
\text { CTRI/2020/07/026300 }\end{array}$ & \\
\hline Inactivated & Inactivated & $\begin{array}{l}\text { Institute of Medical Biology, } \\
\text { Chinese Academy } \\
\text { of Medical Sciences }\end{array}$ & SARS-CoV2 & $\begin{array}{l}\text { Phase } 1 / 2 \\
\text { NCT0 } 4470609 \\
\text { Phase } 1 \\
\text { NCT0 } 4412538\end{array}$ & \\
\hline Protein Subunit & $\begin{array}{l}\text { Full length recombinant } \\
\text { SARS-CoV2 glycoprotein } \\
\text { nanoparticle vaccine } \\
\text { adjuvanted with Matrix M }\end{array}$ & Novavax & SARS-CoV2 & $\begin{array}{l}\text { Phase } 1 / 2 \\
\text { NCT0 } 4368988\end{array}$ & $\begin{array}{l}\text { RSV, CCHF, } \\
\text { HPV, VZV, } \\
\text { EBOV }\end{array}$ \\
\hline Protein Subunit & RBD-based & Kentucky Bioprocessing, Inc & SARS-CoV2 & $\begin{array}{l}\text { Phase } 1 / 2 \\
\text { NCT0 } 4473690\end{array}$ & \\
\hline RNA & 3 LNP-mRNAs & $\begin{array}{l}\text { BioNTech/Fosun } \\
\text { Pharma/Pfizer }\end{array}$ & SARS-CoV2 & $\begin{array}{l}\text { Phase } 1 / 2 \\
2020-001038-36 \\
\text { NCT04368728 } \\
\text { ChiCTR2000034825 }\end{array}$ & \\
\hline
\end{tabular}


Table 1 (continued)

\begin{tabular}{|c|c|c|c|c|c|}
\hline Platform & Type of candidate vaccine & Developer & $\begin{array}{l}\text { Coronavirus } \\
\text { target }\end{array}$ & $\begin{array}{l}\text { Current stage of clinical } \\
\text { evaluation/regulatory } \\
\text { status- Coronavirus candi- } \\
\text { date }\end{array}$ & $\begin{array}{l}\text { Same platform for } \\
\text { non-Coronavirus } \\
\text { candidates }\end{array}$ \\
\hline $\begin{array}{l}\text { Non-Replicating } \\
\text { Viral Vector }\end{array}$ & Adeno-based & Gamaleya Research Institute & SARS-CoV2 & $\begin{array}{l}\text { Phase } 1 \\
\text { NCT04436471 } \\
\text { NCT04437875 }\end{array}$ & \\
\hline Protein Subunit & $\begin{array}{l}\text { Native like trimeric subunit } \\
\text { spike protein vaccine }\end{array}$ & $\begin{array}{l}\text { Clover Biopharmaceuticals } \\
\text { Inc./GSK/Dynavax }\end{array}$ & SARS-CoV2 & $\begin{array}{l}\text { Phase } 1 \\
\text { NCT04405908 }\end{array}$ & $\begin{array}{l}\text { HIV, REV, } \\
\text { Influenza }\end{array}$ \\
\hline Protein Subunit & $\begin{array}{c}\text { Recombinant spike protein } \\
\text { with Advax }{ }^{\mathrm{TM}} \text { adjuvant }\end{array}$ & Vaxine Pty Ltd./Medytox & SARS-CoV2 & $\begin{array}{l}\text { Phase } 1 \\
\text { NCT0 } 4453852\end{array}$ & \\
\hline Protein Subunit & $\begin{array}{l}\text { Molecular clamp stabilized } \\
\text { spike protein with MF59 } \\
\text { adjuvant }\end{array}$ & $\begin{array}{l}\text { University of } \\
\text { Queensland/CSL/Seqirus }\end{array}$ & SARS-CoV2 & $\begin{array}{l}\text { Phase } 1 \\
\text { ACTRN12620000674932p }\end{array}$ & $\begin{array}{l}\text { Nipah, Influenza, } \\
\text { Ebola, Lassa }\end{array}$ \\
\hline RNA & LNP-nCoVsaRNA & Imperial College London & SARS-CoV2 & $\begin{array}{l}\text { Phase } 1 \\
\text { ISRCTN17072692 }\end{array}$ & $\begin{array}{l}\text { EBOV, LASV, } \\
\text { MARV, lnf } \\
\text { (H7N9), RABV }\end{array}$ \\
\hline RNA & mRNA & Curevac & SARS-CoV2 & $\begin{array}{l}\text { Phase } 1 \\
\text { NCT04449276 }\end{array}$ & $\begin{array}{l}\text { RABV, LASV, } \\
\text { YFV, MERS, } \\
\text { Inf A, ZIKV, } \\
\text { DENV, NIPV }\end{array}$ \\
\hline RNA & mRNA & $\begin{array}{l}\text { People's Liberation Army } \\
\text { (PLA) Academy of Military } \\
\text { Sciences/Walvax Biotech }\end{array}$ & SARS-CoV2 & $\begin{array}{l}\text { Phase } 1 \\
\text { ChiCTR2000034112 }\end{array}$ & \\
\hline VLP & $\begin{array}{l}\text { Plant-derived VLP adjuvanted } \\
\text { with GSK or Dynavax adjs. }\end{array}$ & Medicago Inc. & SARS-CoV2 & $\begin{array}{l}\text { Phase } 1 \\
\text { NCT04450004 }\end{array}$ & $\begin{array}{l}\text { Flu, Rotavirus, } \\
\text { Norovirus, } \\
\text { West Nile virus, } \\
\text { Cancer }\end{array}$ \\
\hline
\end{tabular}

24 candidate vaccines in clinical evaluation

CCHF Crimean Congo hemorrhagic fever; ChAdOx1-s Chimpanzee adenovirus Oxford 1-spike; DNA Deoxyribonucleic acid; $D E N V$ Dengue virus; $E B O V$ Ebola virus; HIV Human immunodeficiency virus; HPV Human papilloma virus; Inf A Influenza A virus; LASV Lassa virus; $L N P$ Lipid nano particle; MARV Marburg virus; MenB Meningococcal B; MERS Middle East respiratory syndrome; MF59 First oil in water adjuvant; $m R N A$ Messenger ribonucleic acid; $n C o V s a$ Novel Corona virus spike a protein; $N I P V$ Nipah virus; $R A B V$ Rabies virus; $R B D$ Receptor binding domain; $R S V$ Respiratory syncytial virus; $S A R S$ Severe acute respiratory syndrome; SARS-CoV2 Severe acute respiratory syndrome Corona virus 2; TB Tuberculosis; VLP Virus like particle; $V Z V$ Varicella Zoster virus; YFV Yellow fever virus; ZIKV Zika virus

after challenge, and limited inflammation or detectable viral genome or antigen was noted in lungs of animals in either vaccine group. These findings led the manufacturer along with National Institute of Health and National Institute of Allergy and Infectious Disease USA to undertake Phase 1 clinical trial which has shown favorable result. In this trial, healthy subjects were given two doses of mRNA-1273 vaccine at day 0 and 29th day. The mRNA-1273 vaccine was immunogenic, inducing robust binding antibody responses to both full-length S-2P and receptor-binding domain in all participants after the first vaccination in a time- and dosedependent fashion. Before the next dose, the pseudovirus neutralizing antibody level was found to be low and hence there is a need for a second dose of the vaccine. Following Phase 1 trial 600 healthy subjects were injected with either $50 \mu \mathrm{g}$ or $100 \mu \mathrm{g}$ doses of the vaccine and the response with the higher dose has been found to be favorable. Presently a Phase 3 trial with large number of subjects is already in progress $[8,9]$.

\section{Sinovac Inactivated SARS-CoV2 /Wuhan Institute of Biological Products/Sinopharm and Beijing Institute of Biological Products/ Sinopharm Vaccine}

All three Institutions in China have produced a purified inactivated SARS-CoV2 virus candidate vaccine. All the three candidate vaccines have successfully undergone Phase $1 / 2$ trial and produced SARS-CoV2 specific neutralizing antibodies. Sinovac vaccine (PICOVacc) produced partial or complete protection in Rhesus Macque against SARS-Cov2 challenge without observable antibody dependent enhancement of infection with two different dose schedule of 3 and $6 \mu \mathrm{g}$ [10].

All the above three Chinese inactivated vaccines are in Phase 3 clinical trial in China and other countries specially in Brazil where 6000 subjects are included for Sinovac vaccine trial.

Many more vaccines, mostly in USA, China, Japan, Europe and India are in advanced stages of development. Novavax with financial aid from Coalition for Epidemic 
Preparedness Initiative (CEPI) is developing a protein subunit vaccine containing full length SARS-CoV2 glycoprotein nanoparticle and an adjuvant. The initial results in animal models are satisfactory and the vaccine is now in stage 2 of human trial. Inovio pharmaceuticals from USA is developing a DNA vaccine and the preliminary report on mice and Guinea pig model showed adequate production of neutralizing antibody and is now in advanced stage of human trial.

\section{Indian Vaccine Development}

There are several institutions including academic/research and vaccine manufacturing companies in India which are in the process of development of Covid-19 vaccine. There are four companies listed in WHO website that are in the process of various stages of development. Serum Institute of India, in collaboration with Oxford University and Astra Zeneca is undertaking Phase 3 trial of ChAdOx1 nCoV-19 vaccine in approximately 1600 healthy subjects $18-55$ y of age. On successful completion of Phase 3 trial with one dose of vaccine, the company shall start mass production. Bharat Biotech limited at Hyderabad has two Covid-19 projects at the moment. The first one is in collaboration with Indian Council of Medical Research (National Institute of Virology, Pune) and is already in the process of making an inactivated vaccine by the name 'Covaxin'. The vaccine has undergone successful trial in animal models e.g. mice, rabbit and guinea pigs and following good immunogenicity of the inactivated vaccine, Phase $1 / 2$ clinical trial in several institutions in India has already started. The second project is in collaboration with Thomas Jefferson University where the platform would be vero cell rabies vaccine in which spike protein RNA shall be introduced. The third project of Bharat Biotech is with an American company manufacturing Flu vaccine (Flugen)/Wisconsin University and in the same platform shall be trying to make a live intranasal vaccine. The last two projects are in the initial preclinical stage. Zydus Cadila laboratory has developed a DNA based vaccine (ZyCoV-D). It has another project for development of a replicating viral vector vaccine (pre-clinical stage). After successful animal trial, the DNA vaccine is now undergoing clinical stage $1 / 2$ trial in human subjects. Biological Evans Ltd. is in pre-clinical stage of development of a viral subunit vaccine and Indian Immunological with Griffith University is in very early stage of development of a live attenuated vaccine. All indigenous vaccines would take at least 6-9 mo time to be available in the market subject to successful result of immunogenicity and safety. However, none of the two Indian companies who are in phase $1 / 2$ trials have published the reports of animal studies in public domain till the submission of the present review.
Challenges in Covid-19 Vaccine Development

There are several challenges in the development of any new vaccine including SARS-CoV2 vaccine. The novel SARS$\mathrm{CoV} 2$ virus is fast undergoing drift and several genomic changes have been identified. The most effective way of confirming the efficacy of a vaccine is to challenge the subjects with the offending organism and observe the occurrence of the disease in vaccine recipients in comparison to control population. However, in Covid-19, this experiment shall be unethical since the disease is still evolving and there is no effective treatment for the disease. It is difficult to state at this time the safety and efficacy of the vaccines in development until Phase 3 clinical trial data are examined properly. It is still debatable whether neutralizing antibody is sufficient and what is the critical level of antibody that is protective. The T cell response and cell-mediated immunity of the vaccine may be required for efficacy of the vaccine which also needs to be answered in clinical trials. The amount of antigen dose, the number of doses, duration of immunity and need for booster needs to be answered. Presently all the trials are done on healthy individuals and would require proving in individuals who are at high risk including children, immunocompromised, senior citizens, diabetes, heart disease etc. The safety of the vaccine can only be judged when a large number of subjects are studied in different ethnic and geographical locations. Considering that a safe and effective vaccine will be available, equitable distribution for the most vulnerable shall be a major challenge. The logistics of procurement, supply, storage, cold chain and administration at community level shall be a gigantic task to fulfil. By the time a safe and effective vaccine against Covid-19 disease becomes available and logistics are sorted out, it may happen that the pandemic is already declining and may be over.

\section{Conclusions}

Vaccination is one of the most cost-effective strategy for prevention of diseases. A safe and effective vaccine against SARS-CoV2 virus might be available by the end of 2020 or beginning of 2021. Even if a safe and effective vaccine is available, it may not be possible to obtain the required number of doses, cold chain maintenance, cost and other logistics of mass vaccination specially in developing countries like India. With the public sector investing heavily in the development of these vaccines, there are growing calls for universal vaccine accessibility, but nationalistic, geographical, and commercial factors could stand in the way. The vaccine therefore may not be the only panacea for the prevention and stopping of the pandemic, if it continues. We might have to follow general hygienic measures including, hand wash, wearing mask, cough and sneeze etiquette and social distancing for some 
more time before the pandemic of Covid-19 gets over on its own.

\section{Compliance with Ethical Standards}

Conflict of Interest None.

\section{References}

1. WHO Coronavirus Disease (COVID-2019) Situation Reports. 2020. Available at: https://www.who.int/emergencies/diseases/ novel-coronavirus-2019/situation-reportsr. Accessed 30 July 2020.

2. Draft Landscape of Covid19 Candidate Vaccines. Available at: https://www.who.int/publications/m/item/draft-landscape-ofcovid-19-candidate-vac. Accessed 27 July 2020.

3. Douglas RG, Samant VB. The vaccine industry. In: Plotkins SA, Orenstein WA, Offit PA, editors. Vaccine. 6th ed. China: Saunders Elsevier; 2013. p. 33-43.

4. Le Thanh T, Andreeadakis Z, Kumar A, et al. The COVID-19 vaccine development landscape. Nat Rev Drug Discov. 2020;19: 305-6.

5. Doremelan VN, Lambe T, Spencer A, et al. CHAdOX1 nCov-19 vaccination prevents SARS Cov2 pneumonia in Rhesus Macques.
Available at: Pre print https://doi.org/10.1101/2020.05.13.09315 dated May 13, 2020. Accessed 30 July 2020.

6. Flogetti PM, Aley PK, Becker S, Rmmerstorfer SB. Safety and immunogenicity of the ChAdOx $1 \mathrm{nCoV}-19$ vaccine against SARS-CoV2: a preliminary report of a phase $1 / 2$, single-blind, randomized control trial. Lancet. Available at: https://doi.org/10.1016/ s0140-6736(20)31604-4. Accessed 31 July 2020.

7. Zhu FC, Li YH, Guan XH, et al. Safety, tolerability, and immunogenicity of a recombinant adenovirus type- 5 vectored COVID-19 vaccine: a dose-escalation, open-label, non-randomised, first-inhuman trial. Lancet. 2020;395:1845-54.

8. Corbett KS, Flynn B, Foulds KE, Francia JR. Evaluation of the mRNA-1273 vaccine against SARS CoV2 in nonhuman primates. NEJM. Available at: https://doi.org/10.1056/NEJMoa2024671. Accessed 31 July 2020.

9. Jackson LA, Anderson EJ, Rouphael NG, et al. An mRNA vaccine against SARS-CoV-2 — preliminary report July 14, 2020. DOI: https://doi.org/10.1056/NEJMoa202248. Available at: https:// www.nejm.org/doi/full/10.1056/NEJMoa2022483?query= featured_home. Accessed 26 July 2020.

10. Gao Q, Bao L, Mao H, et al. Development of an inactivated vaccine candidate for SARS CoV-2. Science. 2020;369:77-81. Available at: https://doi.org/10.1126/science.abc1932. Accessed 31 July 2020.

Publisher's Note Springer Nature remains neutral with regard to jurisdictional claims in published maps and institutional affiliations. 